\title{
Poetry as Social Practice in the First Person Plural: A Dialogue on Documentary Poetics
}

\author{
Philip Metres and Mark Nowak
}

Mark Nowak is a documentary poet, social critic, and labor activist, whose writings include Shut Up Shut Down and the recently published book on coal mining disasters in the US and China, Coal Mountain Elementary. Nowak's poetry engages central issues of work, family, and community. His verse play on Reagan's firing of striking PATCO air traffic controllers, "Capitalization," has been staged at theaters (Stage Left in Chicago, the Cleveland Public Theatre) as well as rallies for striking Northwest Airlines mechanics. He is one of a dozen poets included in the seminal anthology American Poets in the 21st Century: The New Poetics. Nowak's unique work, which brings innovative aesthetics and working-class communities into dialogue, has resulted in a dynamic array of projects and publications. Following a model he designed at Ford plants in the United States and South Africa (through the United Auto Workers and the National Union of Metalworkers of South Africa), Nowak's transnational worker-to-worker poetry dialogues create a unique opportunity for working people to analyze, communicate, and express (through poetry) their ideas and emotions about their work, particularly in workspaces experiencing the effects of downsizing, plant closings, worker-management tensions, and strikes. He is currently Director of the Rose O'Neill Literary House at Washington College.

Philip Metres is the author of numerous books, including To See the Earth (poetry), Come Together: Imagine Peace (anthology of peace poems), Behind the Lines: War Resistance Poetry on the American Homefront since 1941 (criticism), and Catalogue of Comedic Novelties: Selected Poems of Lev Rubinstein. His poetry has appeared in a variety of journals and anthologies, including Best American Poetry and Inclined to Speak: Contemporary Arab American Poetry. He has been 
involved in the peace movement since the 1980s; he co-founded the Bloomington [Indiana] Coalition for Peace in the 1990s, and has worked with Pax Christi, Committee for Peace in the Middle East, Peace Action, and Tikkun. He teaches literature and creative writing at John Carroll University in Cleveland, Ohio. Were it not for Ellis Island, his last name would be Abourjaili.

METRES: Documentary poetry is fundamentally concerned with cultivating historicity, nor is it averse to the pedagogical or didactic. Coal Mountain Elementary $(C M E)$, even in its title, foregrounds strongly the pedagogical/didactic. The "elementary" refers to the project as a primer on the experience of coal miners and their families. At the same time, it interrogates the use and manipulation of education and mass media journalism - in particular, through the sampling of the exercises generated by the U.S. coal industry and the Xinhua wire stories (a numbing catalogue of Chinese mining accidents). Historian Howard Zinn called the book "a stunning educational tool." Could you talk a bit about how you see $C M E$, and the larger project of documentary poetry/poetics, in how it complicates the dogma that poetry should avoid instruction?

NOWAK: The first interview in a book I've been reading this weekend, Cesare Casarino \& Antonio Negri's In Praise of the Common: A Conversation on Philosophy and Politics, is titled "A Class-Struggle Propaedeutics, 1950s-1970s." Propaedeutics, I had to look up the word, means "preparatory instruction." What, as writers, is our training ground? Who are our teachers? In the interview, Negri discusses his years at the FIAT and petrochemical plants in post-WWII Italy, how he learned to conduct a workers' inquiry [inchiesta operaia], and, importantly, how his writing evolved "strictly on the basis of the [social, working-class] movement's needs" (58). Negri articulates this period to his discovery of Facing Reality, a USbased group that split from the Trotskyists in the 1950s (the book incorrectly says the 1930s) who spent their time on (and at) factories in the States and wrote stunning analyses of the working class movement, including what was a seminal book to me, Facing Reality, co-authored by C. L. R. James, Grace C. Lee (Boggs), and Pierre Chaulieu (aka, Cornelius Castoriadis). In the introduction to Facing Reality is a quote I often cite: "[P] eople all over the world, and particularly ordinary working people in factories, mines, fields, and offices, are rebelling every day in ways of their own invention. [...] Their strivings, their struggles, their methods have few chroniclers" (5). My goal as a writer - to synthesize both Negri and Facing Reality - is to consistently function as this chronicler while simultaneously writing from the working-class movement's needs.

When I was finishing Shut Up Shut Down, I started experimenting with re-creating Marxist theories in poetic forms. The final poem in that book, on the closing of a taconite plant in northern Minnesota's Iron Range, attempts to render Marx's notion of base and superstructure through the haibun, where the economic base (the precise number of workers across the towns in the Iron Range who lost their jobs when the plant closed) concludes the final line of each haiku section of the haibun. In the new book, my overarching goal was to try to render transnational working class history in documentary poetic form. What would a transnational working class history look 
like, I kept asking myself, on the page? $C M E$ is also an attempt to produce both what I've taken to calling "labor history with line breaks"-i.e. the documentary poem as subgenre not only of poetry but also of labor history - and a poetic version of critical pedagogy and labor education as represented by, say, the work of Paul Willis, Michael Apple, and others. The "instruction" theme in my pieces that you mention probably started more than a decade ago in the very first of my tri-vocal works, the poem "Zwyczaj" in Revenants (originally published in the centenary issue of American Anthropologist), which samples from a textbook on the theory and practice of producing ethnographic fieldnotes. It continues in the long poetics theatre piece "Capitalization" where I sample from Cold War-era grammar textbook. CME, with its structure purposely built around three lessons ("Coal Flowers," "Cookie Mining," and "Coal Camps and Mining Towns") extends this into the book-length poem. I'd also add that, as someone who has taught 10-12 classes per year for more than fifteen years at an open enrollment community college, developing innovative instruction materials to use with working adults is simply a substantial part of my everyday existence, and my writing, of course, reflects that.

METRES: Your answer brings to mind Whitman's notion, in his Preface to the 1855 edition of Leaves of Grass, that "poems distilled from other poems will likely pass away." Your poetic project draws upon and extends resources, voices, and narratives that are - in the hothouse of contemporary poetry - richly unusual, and feel more akin to the projects of the field recordings of the WPA in the 1930s, the interviews of Studs Terkel, the histories of Eric Foner and Howard Zinn, etc. What sort of genealogy can you trace for your own poetic labors-both in terms of precedent poets and other language workers (who are not self-consciously "poets")? Was there an epiphanic moment, where you saw it as possible and productive to officiate the marriage of poetry and labor history?

NOWAK: If an epiphany can emerge slowly, say over the course of 44 years and counting, then yes, absolutely. The very first thing I consciously wrote as a poem (as opposed to lyrics I'd penned for the goth-industrial/electronic bands I was in throughout the early- and mid-1980s, a period I've written about in an essay in Goth: Undead Subculture), was an homage of sorts inspired by the person who was then, and in many ways still is, my favorite poet: Gwendolyn Brooks. My first published poem - in the undergrad student literary magazine where I finished my tour of colleges and finally got my degree - was a villanelle that quoted from and improvised upon a newspaper article about a drunk father who set his son on fire; it was called, if I remember, "the alcohol and the pain ignite the boy." It tried, quite unsuccessfully I might add, to employ the lessons I'd learned studying Brooks' more lyric/anthologized poems like "Kitchenette Building" and "The Bean Eaters" as well as everything I'd learned by being an electronic musician working with electronic sampling, listening to Kraftwerk, and heading out to see shows by Grandmaster Flash, Run-DMC, and others. Like Brooks taught me (and like her seminal, largely unanthologized work "In the Mecca" would teach me later), I was simply trying to write about what I knew. I grew up on the east side of Buffalo, the grandson of a woman who dropped out of school in fifth or sixth grade to clean other people's houses and eventually became a "Rosie the Riveter" and a Teamster; 
grandfathers who were steelworkers and train mechanics; a dad who was a union VP at Westinghouse and a mother who was both a clerical worker and sold coats at a department store. If we lived in Chicago, anyone in my family could very easily have been one of Studs Terkel's interviewees for Working.

It's interesting, too, that you mention field recordings, because if there is a single epiphanic moment it was when I moved to Minnesota and decided to take a class on fieldwork methodologies with folklorist Ellen Stekert. In addition to being an incredible singer/performer in the folk revival tradition (including records with Smithsonian/Folkways, such as Songs of a New York Lumberjack), she was perhaps the finest mentor on fieldwork practice and methods who has ever taught. It was in her class that I started reading everything I could get my hands on in oral history, ethnography, folklore... My final project for her course turned out to be the poem "Zwyczaj," which I mentioned earlier. And shortly thereafter I started a lengthy oral history project in both Minnesota's Iron Range and Youngstown, Ohio, with musicians who were miners and steelworkers and who helped create an experimental new musical form called "The Polka Mass." I still have a huge storage crate in the basement full of $100+$ hours of transcribed interviews, rough drafts of chapters, notebooks full of fieldnotes, etc. Around the same time, I started a massive archival project — practically living for several years on the microfilm machines at the Minnesota Historical Society in downtown St. Paul—on the 1916 Iron Range miners strike against U.S. Steel, a worker-initiated industrial action that came to be led by the Wobblies (I.W.W.). Those two unfinished projects were my initiation into labor movement fieldwork, oral history, and archival research. As both projects stalled for various reasons, I started assembling the five serial pieces that became Shut Up Shut Down.

METRES: Ah yes, "These fragments I shore against my ruins." And your vocation, then, has become an attempt to set those (oppressed/repressed/unheard) voices of laborers into play, against the forces that would have them forgotten. I have two questions, the first particular to your project, and the second an attempt to widen our lens a bit. The first question: regarding the ways in which you have come to "shore" those ruins, if "ruin" be the right metaphor at all-how, on a craft level, do you come to choose whose voices get heard, and in concert with what other voices/procedures. The second is a related but more general question, about the whole span of documentary poetry. I've quoted "The Waste Land" here. It seems an irony of literary history that documentary poetry, so often associated with progressive projects, emerges in no small part from Ezra Pound's politically reactionary (though poetically experimental) Cantos and T.S. Eliot's "The Waste Land," and the turn toward a modernist epic by way of collage, fragmentation. But perhaps I'm getting the history wrong, and Pound's work is indebted to visual and musical arts, in particular photography and film. I'm thinking in particular of the early film-making (all of which was avant-garde!). The narrative of our (poetic/political) origins seems at least as important as defining what "documentary poetry" might be, and might become. In the spirit of documentary praxis, we ought not merely list characteristics of "documentary poetry," but talk about the dialectic of documentary. For example, we might say that it is a poetry that foregrounds historicity, but that 
would repress the way in which documentary poetry also operates with recourse to the transhistorical. We could say that documentary is a poetics of the local, but that it works towards how the local becomes synecdochal, becomes representative. We could say that documentary poetry is propaedeutic, but also questions its own instructional impulses (insofar as instruction implies a monodirectional trajectory of knowledge). We could say that documentary poetry foregrounds the materiality of texts, of raw facticity, partly because of its allegiance to the material world, to the actual bodies and language of people in the world and partly because (and here's where my first question and the second connect) in the process of composing documentary poetry, we are constantly forced to leave things out, to create a frame, a narrative. So the strengths of documentary poetry - its attention to preserving a history, its instructionality, its architectures - also risk the violence of silencing, naming, excluding that the documentary poetry attempts to redress.

NOWAK: "The basic form is the frame"- those are the very first words in Shut Up Shut Down, and it was precisely the "dialectics of documentary" that you outline which these opening lines, and the book as a whole, attempt to address. And forgive me for consistently turning away from poetry, but for my own work, documentary film has been a much more encouraging teacher. If we trace the lineage in motion pictures, we arrive directly at the workplace and the working class with Louis Lumèire's Workers Leaving the Lumière Factory (1895) - thirty years before the first publication of Pound's A Draft of XVI Cantos. Documentary cinema literally starts at the factory gates (and many of the film's implications have been magnificently deconstructed in Harun Farocki's documentary/archival film-essay, Workers Leaving the Factory). Might we argue that documentary film has been more socially constructed/constructive than documentary poetry, both at its inception and since? And that documentary film, today, is much more vigilant in its social address than contemporary poetry? In the past year or so, what would be the equivalents in poetry to, say, Ulrike Franke and Michael Loeken's Losers and Winners, an extraordinary transnational labor documentary.

As to your silencing and exclusion question: it will perpetually be a generative question because documentary can never be reality but only represent a small sliver of reality envisioned and rebuilt through that basic form, the frame (be it photographic lens, cinema/computer/TV screen, or page). In assembling just the boldface voice (the story of the Sago mine disaster as told in the testimonies of miners and mine rescue team members) in Coal Mountain Elementary, I read and analyzed more than 6,300 pages of testimony to come up with the forty-eight brief quotations that comprise that trajectory of the storyline; 6,250+ pages were excluded from my documentary retelling. That's a lot of silencing and exclusion. The option, to me, seems to be the ongoing silencing of these miners and mine rescue team members by the placement of their version of the story within 6,300 pages of government testimony that few, beside myself, would ever read. And perhaps this gets us back to documentary propaedeutics, to the early nomenclature of documentaries as "educationals" (as Patricia Aufderheide cites in her new book, Documentary Film: A Very Short Introduction). Certainly works like Richard Wright's 12 Million Black Voices, Muriel Rukeyser's The Book of the Dead, Frederick Wiseman's High School, and Howard Zinn's A 
People's History of the United States were "educationals" for me.

METRES: There is a danger in becoming paralyzed by the potential (and actual) epistemic violence of every poetic choice we make, the violence of framing, yet to not speak seems an abnegation of our responsibilities and opportunities, as intellectuals and artists who have recourse to working with language, as subjects of empire and as global citizens. Whatever inner Derridean (and Spivakian) I answer to, I still will err on the other side of silence. Your particular poetics - insofar as all your framings tend to foreground their own limits, and your language employment foregrounds its own materiality — arguably resists the tendencies of a leftist narrative that makes absolute truth claims (i.e., "you've heard the official narrative, now I will give you the truth"). I'd like to press a bit more into the area of craft, if only for selfish reasons, regarding Coal Mountain Elementary. What I can glean is that, like Shut Up Shut Down, you work with/sample/collage three or four sources (an oral testimony, news reports, a teaching lesson, and documentary photographs). Yet in $C M E$, a distinct narrative through-line develops around the oral narrative of a rescue team that goes into the Sago mine and retrieves the corpses of miners that the community believed were still alive. So you began with over 6,000 pages, and discovered this testimony, this story. Can you talk a bit about that discovery, and how this story became an embodiment of the trauma and exploitation experienced by mine workers?

NOWAK: My new books always seem to develop out of self-criticisms of my previous books. Revenants, my first book, introduced (in “Zwyczaj”) this three-voice technique - the overdetermination of the dialectic or the dialectic plus one, i.e., the tri-vocal - which is my structural or craft-based technique for textually disempowering absolute truth claims. I found myself disappointed when I went on the road to read from the book to what seemed to me an already pre-determined, pre-constructed audience. If I went to, say, the Poetry Project (a space where I still love to read), I expected that the audience would be composed of poets A through Z. And it was. And that was it. Even though my book, I felt, addressed deindustrialization and the collapse of certain sectors of the urban geography (Alan Gilbert's essay on Revenants, in his fantastic book Another Future: Poetry and Art in a Postmodern Twilight, does the best job of reading it in this way), the book was never able to enter into these larger conversations. Some might say, oh, the mainstream media or culture at large doesn't appreciate poetry, doesn't read poetry, you know the arguments - but to a much larger extent I took this as a critique of my own poetic practice.

During the process of assembling Shut Up Shut Down, I consciously attempted to construct a new audience, a new social space, for the potential reception of my work and other new works that might emerge in this vein. Before the book was published, the premiere of the verse play "Francine Michalek Drives Bread," about a Taystee bakery truck driver whose husband is killed in a mining accident and who takes a more activist role in her Teamsters local, premiered at UAW Local 879 union hall across the street for the Ford plant in St. Paul. The audience, uniquely, was split half-and-half between people from the literary community (and those split evenly among poetry and theater people) and workers from the Ford plant along with activists from various unions. I was then invited to read from the book at a union fundraiser at the United Food and Commercial Workers (UFCW) Local 789, to read sections 
from the book at a rally for graduate students trying to unionize at the University of Minnesota through the United Electrical, Radio, and Machine Workers (UE), etc. Once the book was published, the terrain of the conversations continued to expand. When Northwest Airlines mechanics and cleaners (AMFA Local 33) went on strike, I was invited to read from the PATCO/McCarthyism verse-poem ("Capitalization") at their major rally. I started getting calls for interviews from labor radio shows in places like Milwaukee and Kansas City and reviewed not only in poetry journals but in publications like Labor History. Overall, I was trying my best to interrogate, as John Beverley puts it in Testimonio: On the Politics of Truth, "the way literature itself was positioned as a social practice" (53). I should also mention here in passing that Beverley's writing on Ernesto Cardenal and Rigoberta Menchú, particularly the notion of a "polyphonic testimonio" as opposed to the classic first-person singular testimonio, was important in my imagining the first-person plural "through-line" of the miners' story in $C M E$, which is not one person's testimony but testimonies from 75 interviews montaged into a collective first-person plural.

But it was when I began, shortly after the Sago mine disaster in early 2006, teaching poetry workshops between shifts inside the closing Ford assembly plant in St. Paul (and later at Ford plants in Port Elizabeth and Pretoria, South Africa), that my own self-criticisms of Shut $U p$ began to arise. Given the project of re-positioning my poetry as social practice, the speed, if you will, of the montage, of the jump cuts, in Shut $U p$ felt too quick for me. And particularly given the nature of the stories in $C M E$, both in West Virginia and China, I purposely wanted, to go back to film comparisons again, to transition from the consciously Dziga Vertov style and techniques of Shut $U p$ to something much slower, something more like Frederick Wiseman, in Coal Mountain. I felt that this story of the death of 15,000 coal miners in a three-year period in China (or much more, depending on whether you go by government statistics or those of, say, the Chinese Labor Bulletin - the great project of Han Dongfang) and this utterly devastating, heart-wrenching story at the Sago mine in West Virginia needed to be assembled in such a way that the structures shifted at a more deliberate pace. And again, in terms of violence and truth-claims, it has been vital for me to continually produce and share this work, right from the beginning and repeatedly, in West Virginia, in and around the Sago mine. So in 2006, just a few weeks after the disaster, I spent a week at Davis \& Elkins College, maybe twenty-five minutes from Sago, as a visiting writer. It was then that I shot most of the photographs at mines in the region, spoke to people in the community, facilitated workshops on working class writing and labor history. The next year, I was brought back to Davis \& Elkins, this time so that the "through-line," as you called it - the boldface Sago testimony story - could be premiered by the college's theater department as a documentary play. It was during that visit when I met people whose parents, uncles, and cousins worked at the Sago mine and I got to hear their incredibly supportive responses to my work. I remember one person from the audience in particular who said to me, "People come in and represent West Virginians in a certain way. And I just want to thank you for not doing that. I just heard us in here."

Now, the first public events around the book's publication include students from the D\&E theater department coming up by bus and staging the book at the University 
of Pittsburgh's theater department as well as it being their spring 2009 production at the Boilerhouse Theater back in Elkins. The mix for $C M E$ 's potential reception is now quite different than it was for Revenants a decade ago. In a period of about ten days, I spoke at not only an MFA program, an Appalachian literature class, and two theater departments, but also a history department (the chair, at West Virginia University, is a fine labor historian, Elizabeth Fones-Wolf), the AFL-CIO's National Labor College, a conference of labor educators (UALE), an anarchist bookstore/ infoshop in Baltimore (Red Emma's), the John L. Lewis Memorial Museum of Mining and Labor in the tiny town of Lucas, Iowa, and an annual labor history lecture series run by the St. Paul public library. That, to me, is just one version of what is possible for the repositioning of poetry as social practice.

METRES: Your answer anticipated my question about the "slowing-down" of this book compared to Shut Up Shut Down, whose experimental use of jump cuts feels much more self-conscious than $C M E$. You have opened up the page so that the multivocality of the piece unfolds over separate page-fields rather than in the simultaneity effect of Shut Up. The poet in me wants to say that Shut Up is more "poetic" in its treatment of language, the line, and syntax, and that CME is, in some sense, more "dramatic" or even "novelistic" - particularly in the way that the whole book could be read as a single work broken into chapters. But in such classifications, I'm regressing back to the idea that poetry is essentially an esoteric, hermetic practice of language as such. Though it's clear you're ambivalent about all this poetry talk - for good reason, given the way in which the contemporary poetry that seems most valued by poets is almost a private, occult practice-it's also true that you continue to hold on tenaciously to the idea of poetry as a mode of social practice. Why not just give it up? Maybe poetry (or, at least, the PoBiz) has diminished into a ponzi scheme, an academic dream, a series of coded messages to self, an unpaid leave from reality. I heard a story somewhere about a poet who met a rapper, and called the rapper a great poet. To which the rapper replied, don't call me a poet, I'll never get paid again.

NOWAK: You keep asking about poetry, and I keep going back to documentary film. Sorry! Nevertheless, one of the main structural models of this "slow down" that I had in mind when I started trying to find/create a form for Coal Mountain was Wang Bing's stunning 9-hour long documentary film that I'd seen in its entirety on the big screen a few years earlier, Tie Xi Qu (West of the Tracks). The film powerfully traces the social, human costs of China's transition from state-run industries and a planned economy to the "free" market in the former industrial district of Shenyang - at often excruciatingly slow speeds. The momentum of its constructedness seemed to fit my own project's need for deceleration even though my project is, as you say, more dramatic, though decidedly in the Brechtian as opposed to the Aristotelian sense. Interestingly, I only now realize that both are trilogies - $C M E$ with its three lessons and Tie Xi Qu with its three movements ("Rust," "Remnants," and "Rails"). Perhaps there is also something to the fact that Shut Up (2004) was composed and published in a time of neoliberal economic frenzy while Coal Mountain is a book about crisis that was composed and published during a ferociously slowed global economy/economic crisis. It's a book of tremendous loss 
published during a period of drastic losses in employment, manufacturing jobs, and the historical gains of the post-WWII working classes.

As for the larger question, why poetry, why this ponzi scheme or unpaid leave (both interesting economic metaphors), there are things that poetry carries with it that seem well-suited for the needs of the current crises and my manner of dealing with these crises as an artist. I enjoy, for example, poetry's mobility-especially when compared to documentary film, which requires significant capital investments to produce and distribute. This is one thing that's bothered me about many of the filmmakers I've mentioned: until very recently, to acquire a copy of a film by Frederick Wiseman or Harun Farocki or Wang Bing would require more cash than I, or any of the subjects of these films, would be able to readily lay their hands on. What good is a film about the working classes if it's only viewed and studied by the financial and aesthetic elite who can shell out $\$ 300$ for a DVD? My hope is that emerging digital technologies will democratize this process to some extent. But to be honest, I was having a personal crisis with poetry and at the cusp of abandoning it completely. This was in part the impetus for my essay "Neoliberalism, Collective Action, and the American MFA Industry," where I suggest a historical model of radical writers workshops (the John Reed clubs of the CPUSA, Ernesto Cardenal's talleres de poesia, etc.) as more tenable models for writing praxis and pedagogy than the neoliberal MFA industry. Yet the more important question that I began asking myself, again, my self-criticism, was... well, what are you doing about it other than writing this essay? Then in January 2006 - the same month as the Sago disaster - the Ford Motor Company announced a massive "restructuring" plan ("The Way Forward") that would close a dozen or more plants in the United States and Canada and cost 30,000+ Ford workers their jobs. One of the plants which hung in suspension, one that might or might not close ("purgatory," as one worker put it), was the Twin Cities assembly plant where my play premiered and where I'd hosted meetings of the Political Issues/Action committee of the National Writers' Union when I was chairing that committee in Minnesota. So I spoke with my friends in UAW 879 and proposed a poetry writing workshop at the plant, between shifts, for workers who were interested in writing about what was happening. By the time we got the notice for the workshops in the UAW newsletter, Ford officials announced that the St. Paul plant would indeed be closing, ending an 81-year tradition on the site and costing 1,800 local workers their jobs. For the next several months, I met with interested Ford workers/UAW members who wrote poems about their lives at Ford and what the closing of the plant meant to them, their families, and their community. Several months into these workshops, I received a grant to travel to South Africa to meet with various social movements and writers and give readings from Shut Up Shut Down -- which I did for nearly a month, from Cape Town all the way across to Pretoria. And, with enthusiastic logistical help from the National Union of Metalworkers of South Africa (NUMSA) and COSATU (Congress of South African Trade Unions), I was able to facilitate my first transnational, worker-to-worker poetry dialogues between the Ford workers in Minnesota and those at Ford plants in Port Elizabeth and Pretoria. Those poetry dialogues re-established my faith in poetry. 
METRES: If only to prove your point, I've had Frederick Wiseman's films on my list of movies to watch for twenty years, and I've never been able to find a single copy available in traditional distribution channels (even the great public libraries in Philadelphia and Cleveland, local video stores, etc.). Though I haven't seen Tie Xi Qu (West of the Tracks), the poet Barrett Watten has featured a clip of Manufactured Landscapes during recent conference papers - a haunting exposé (in both senses of the term) that renders visible the massive, alienating, repetitive labor that produces so many of our daily consumables. One small outcome of our dialogue, at least, has been an accruing bibliography for self-education - an endless but necessary labor indeed. I could ask you to talk about fellow contemporaries, such as Watten, whom you see as poet comrades in this sort of work. This, of course, could devolve into shout-outs (though there's nothing wrong with shout-outs). Instead of moving in that circle alone, though, I want to invite you to talk about two areas of your work and thinking that might be generative both for writers and for writing programs. I'm fascinated by the process of doing field recording, and I've experimented with it on a small scale for years, mostly in the form of openended interviews, in which I have people tell stories. In particular, in 2007, I led a group of upper-level creative writing students in a field-gathering of interviews at something called "The Peace Show," an annual Cleveland festival that began as an alternative to the Air Show, which glorifies and sells military might alongside its demonstration of flying prowess. The stories we gathered were short interviews of people attending or participating in the Peace Show, inquiring about how war has affected them and how they were involved in peace work. I encouraged students to generate poems from these stories, though the initial versions were rough. I'm in the process of trying to figure out what to do with them, now that the semester is done, in addition to making them available online. One of the recordings, immediately, seemed to emerge in the form of a sonnet, which I hammered out. But others feel more open-ended. So the first area I'd invite you to speak on is what sort of advice would you give to poets who want to do field recordings, and how these recordings might contribute in some way to poetry, to our histories, and to the movements in which we find ourselves.

NOWAK: I can only speak from my own experiences, Phil. For me, models that meld oral history and theatre-Anna Deavere Smith's Twilight-Los Angeles, for example, or Peter Weiss' expansion of the German documentary/testimony theatre tradition in works like The Investigation and Discourse on Vietnam - have proved to be terrific learning models for the artist side of me. For the labor historian/oral historian side, as I said earlier, studying with (or studying the works of) people who have made a career out of interviewing, collecting oral histories, and writing ethnographies - as Ellen Stekert was for me, as well as the bibliographies of books and articles she urged me to read-was invaluable. Just off the top of my head, books like the collaborative photography/oral history volume by Milton Rogovin and Michael Frisch, Portraits in Steel (which is about the plant where my grandfather worked, Bethlehem Steel in Lackawanna, NY); Richard Feldman and Michael Betzold's End of the Line: Autoworkers and the American Dream (An Oral History); Lila Abu Lughod's classic Veiled Sentiments: Honor and Poetry in 
a Bedouin Society; Kevin Dwyer's Moroccan Dialogues: Anthropology in Question; and of course the countless monographs and other publications in oral history, sociology, anthropology, and related fieldwork practices. Reading these books as a poet and artist always gives me ideas for new ways to structure my future projects.

For me, however, the practice of scholarship must always go hand-in-hand with on-the-ground political projects, be it developing an organization to support and educate workers and community members around the unionization drive at the Borders bookstore in the Twin Cities or my work as poet and labor educator at Ford plants and labor education centers in Minneapolis, Chicago, Johannesburg, and elsewhere. The imperative is to continually engage the dialectical dialogue between theory and practice that Marx speaks of so definitively in Theses on Feuerbach and elsewhere.

METRES: The second area I'd like to invite you to elaborate on is your Platonic (or should I say, Marxist?) vision for a vital, progressive MFA program. While doing these field recordings, I've found that one problem is the monodirectional nature of interview itself. To oversimplify, radically: They "give" it (the raw materials of their lives), I "take" it, and then "work" it into "my" poem. (The more generous way of viewing this dynamic, I guess, is to say that the poet's job is not to illuminate some inner privatized truth, but to become the medium for the voices whose lives have not been heard on the page.) In any case, if you could, rehearse your general plan for a writing program as you do in "Neoliberalism, Collective Action, and the American MFA Industry," and talk a bit about the work you've done in the last few years to offer a space for workers to become the authors of their own poems and narratives (as you termed them above, "dialogues"), as you demonstrate so powerfully in the readings/performances that you're doing these days.

NOWAK: Especially as my essay that you mention has just turned up (and been summarily dismissed) in the new issue of the AWP Chronicle, I'd rather speak to the idea of the creative writing workshop as a form of radical pedagogy outside the milieu of graduate writing programs than engage in some utopian exercise on curriculum development for a "progressive MFA" if that's okay. Instead, let me talk briefly about my current work in the first person plural-as opposed to what I see as the MFA world's predominantly dogged individualism rooted in the first person singular - the Rufaidah Poetry Dialogues. When I returned from my workshops at the Ford plants in Pretoria and Port Elizabeth, I was on the road quite a bit giving lectures on the workshops, though interestingly not at the invitation of university creative writing programs but from, for example, the curator of an exhibit on "Workers Culture in Two Nations" in Michigan, a public library labor history series - cosponsored by the UAW - at the Ford plant in St. Paul (where more than 150 workers and retirees and their families showed up), and a lecture at the Working Class Studies Association.

My larger idea when I returned was to experiment with the facilitation of "poetry dialogues" in different sectors of the economy - manufacturing, service, health care, etc. - and to see what might develop in each of these sectors. In the spring of 2008 I was invited to be a visiting professor at the University of Minnesota, and Paula Rabinowitz, chair of the department, asked if I would teach a senior seminar on my poetry dialogues. Rather than perform an autopsy on my own recent projects, I devised a syllabus in which students would read extensively in critical pedagogy 
(Freire's Pedagogy of the Oppressed, etc.), community-based or more innovative institutional forms of creative writing workshops (like June Jordan's Poetry for the People), and related works. Students were then required to design, facilitate, and document their own "poetry dialogues" at their places of work. For the final exhibition, students created radio shows with GarageBand of the co-workers' poetry, short documentary films with iMovie (some posting them on Youtube), etc. One of my favorites, among many, was a student who worked the night shift at UPS who led poetry workshops inside the back of the UPS delivery trucks with his co-workers; he videotaped the final night of these workshops and made a fantastic documentary film that he showed to the class. In order to try to renegotiate hierarchies and power relationships in the classroom, I promised students that I would simultaneously design, facilitate, and document my own "poetry dialogue" along with them. For an entire semester, I worked with members from AFSCME 3800, the clerical workers at the University of Minnesota who twice within a five-year period had gone on strike against the university. AFSCME clerical workers from a broad range of departments came to the workshops where we read poems by other clerical workers-Wanda Coleman's "Drone" and poems by UC-San Francisco clerical worker and AFSCME 3218 member Carol Tarlen, for example - and then composed new works of our own. This dialogue culminated at an event that was part of the "Late American Poetics and the Politics of Exception" symposium-which also involved both Flagg Miller and Marc Falkoff discussing at length their seminal Poems from Guantanamo: The Detainees Speak volume. At the symposium the clerical workers read their poems about their work and about the strike to a large audience of university students, professors, administrators, and fellow AFSCME 3800 members. At the end of the reading, everyone in the audience wrote brief anonymous poems back to the clerical workers which I quickly orchestrated into a choral response performance by several of my students - a little like my Ford workers' choral poem, "Oh! What a Life!," from the shop stewards at the Pretoria plant. Let me just say that both the AFSCME clerical workers' poems as well as the choral community response poems brought an often tearful momentary collectivity to what was at times a bitter struggle at the university workplace.

My next, and current, round of poetry dialogues is with a support and advocacy organization for Muslim healthcare workers that's just trying to get its feet on the ground: Rufaidah (named after the first known Muslim nurse, Rufaidah bint Sa'ad). It's a collaboration with two of my former students who are now RNs at local hospitals, Rahma Warsame and Nimo Abdi. Healthcare workers-from entry-level home health workers to RNs - meet once a month to examine and analyze their working conditions through both critiquing and writing poetry. Our sessions began with close readings of Walt Whitman's "The Wound Dresser" and then extended into the writing of poems about the healthcare workers' memories (and later adding their family members' memories) of both the civil war in Somalia/Mogadishu - all the participants in the early sessions of this dialogue were born in Somalia - and how the injured were treated and cared for during a civil war that has occurred many years and across an ocean from the one addressed by Whitman. Our goal is to eventually hold a series of "poetry dialogues" with local 
and national nurses unions - an area that has become so tense in the past few years and escalated into violence between the SEIU and the California Nurses Association-as well as traveling, as a group, to engage in both "poetry dialogues" and healthcare education/practice with organizations and healthcare workers in Africa. That is our long-term objective.

In the end, if I could offer any challenge to writers and writing programs, it would be to radically re-imagine both the way literature is positioned as a social practice and what might be possible in the first person plural. I think we need to push beyond, far beyond, collaborative writing projects between, say, pairs of already established writers; we also need to push to extend into many more cultural arenas programs such as poets in the school/prisons (both of which I've participated in, and which continue to be necessary in this era of cuts to public education, NCLB ("No Child Left Behind"), the rise of the prison industrial complex and incarceration rates, etc.). I believe we need this push to more radical innovations in collaborative projects that, as Negri says in the quote at the very beginning of our dialogue, evolve "strictly on the basis of the [social, working-class] movement's needs." This requires emerging from, as you call it, the "esoteric, hermetic practice" of writing in the first person singular to a radical redrawing of the map of poetry as social practice in the first person plural. I often say that there are Marxists who explicate the intricacies of Adorno's aesthetic theory and the Grundrisse at the dinner table and Marxists who volunteer to help wash the dishes in the kitchen; and I have always have been and will always be in the latter wing of the "revolutionary cadre," my friend... always.

METRES: In the margins of my copy of Coal Mountain Elementary, I wrote: "I'm reading this while Amy [my wife] folds laundry." I'm still getting educated. But it's the poem that made that realization happen. Thanks, Mark.

\section{Works Cited}

Abu-Lughod, Lila. Veiled Sentiments: Honor and Poetry in a Bedouin Society. Berkeley: University of California Press, 1986.

Apple, Michael. Ideology and Curriculum. 1979. Routledge: New York, 2004.

Aufderheide, Patricia. Documentary Film: A Very Short Introduction. Oxford: Oxford University Press, 2007.

Beverley, John. Testimonio: On the Politics of Truth. Minneapolis: University of Minnesota Press, 2004.

Brooks, Gwendolyn. Blacks. Chicago: The David Company, 1987.

Casarino, Cesare, and Antonio Negri. In Praise of the Common: A Conversation on Philosophy and Politics. Minneapolis: University of Minnesota Press, 2008.

Charara, Hayan, ed. Inclined to Speak: an Anthology of Contemporary Arab American Poetry. Fayetteville, Arkansas: University of Arkansas Press, 2008.

Dwyer, Kevin. Moroccan Dialogues: Anthropology in Question. Baltimore: Johns Hopkins University Press, 1982.

Falkoff, Marc. Poems from Guantánamo: The Detainees Speak. Iowa City: University of Iowa Press, 2007.

Feldman, Richard, and Michael Betzold. End of the Line: Autoworkers and the American Dream (An Oral History). Urbana: University of Illinois Press, 1990. 
Freire, Paulo. Pedagogy of the Oppressed. 1970. New York: Continuum, 2000.

Gilbert, Alan. Another Future: Poetry and Art in a Postmodern Twilight. Middletown: Wesleyan University Press, 2006.

High School. Dir. Frederick Wiseman. 1968.

James, C. L. R., Grace C. Lee (Boggs), and Pierre Chaulieu (aka, Cornelius Castoriadis). Facing Reality. 1958. Detroit: Bewick Editions, 1974.

Jordan, June. Poetry for the People: A Revolutionary Blueprint. New York: Routledge, 1995.

Losers and Winners. Dir. Ulrike Franke and Michael Loeken. 2006.

Metres, Philip. Behind the Lines: War Resistance Poetry on the American Home Front since 1941. Iowa City: University of Iowa Press, 2007.

---.To See the Earth. Cleveland, OH: Cleveland State University Poetry Center, 2008.

Metres, Philip, Ann Smith and Larry Smith (ed.). Come Together: Imagine Peace. Huron, OH: Bottom Dog Press, 2008.

Nowak, Mark. Coal Mountain Elementary. Minneapolis: Coffee House Press, 2009.

---. "Neoliberalism, Collective Action, and the American MFA Industry." ;Workers of the Word, Unite! Long Beach: Palm Press, 2005.

---. "To commit suicide in Buffalo is redundant': Music and Death in Zero City, 1982-1984." Goth: Undead Subculture. Durham: Duke University Press, 2007.

---. Revenants. Minneapolis: Coffee House Press, 2000.

---. Shut Up Shut Down. Minneapolis: Coffee House Press, 2004.

Rankine, Claudia and Lisa Sewell, ed. American Poets in the $21^{\text {st }}$ Century: the New Poetics. Middletown, CT: Wesleyan University Press, 2007.

Rogovin, Milton, and Michael Frisch. Portraits in Steel. Ithaca: Cornell University Press, 1993.

Rubenstein, Lev, Philip Metres and Tatiana Tulchinsky. Catalogue of Comedic Novelties. Brooklyn, NY: Ugly Duckling Presse, 2003.

Rukeyser, Muriel. The Book of the Dead. 1938. The Collected Poems of Muriel Rukeyser. Pittsburgh: University of Pittsburgh Press, 2006.

Smith, Anna Deavere. Twilight_Los Angeles, 1992. New York: Anchor Books, 1994.

Tie Xi Qu (West of the Tracks). Dir. Wang Bing. 2004.

Weiss, Peter. Discourse on Vietnam. 1967. London: Calder and Boyars, 1970. The Investigation. 1965. New York: Atheneum, 1966.

Whitman, Walt. Leaves of Grass. 2nd ed. New York: W.W. Norton. 2002, 1855-92.

Willis, Paul. Learning to labor: How working class kids get working class jobs. New York: Columbia University Press, 1982.

Workers Leaving the Factory. Dir. Harun Farocki. 1995.

Workers Leaving the Lumière Factory. Dir. Louis Lumèire. 1895.

Wright, Richard. 12 Million Black Voices. 1941. New York: Thunder's Mouth Press, 1988.

Zinn, Howard. A People's History of the United States. 1980. New York: Harper Perennial, 2003. 